\title{
Application of Malay Traditional Architecture Elements as Regional Identity towards Sustainable City
}

\author{
Wahyu Hidayat ${ }^{1}$ \\ ${ }^{1}$ Department of Architecture, Universi ty of Riau, Indonesia \\ hidayat79_iium@yahoo.com
}

\begin{abstract}
Development of a sustainable city is a complex process with interactions of numerous aspects such as economic, environment, and social in urban living. Architecture is a major part in creating identity or character of the city and influencing quality of life of city community. In the context of architecture and urban design, sustainable architecture can be achieved if cultural aspects and ecological aspects are synergized as two connected entities. The study aims to identify and to analyse the application of Malay traditional architecture elements in contemporary buildings design in Pekanbaru. The assessment is based on two variables which are cultural aspect that shows application of Malay traditional architecture character as regional identity and ecological aspect that reflects application of Malay traditional architecture elements to respond the climatic condition. This research use qualitative methodology to analyse form and character of the buildings in term of application of Malay traditional architecture elements, and quantitative methodology is used with descriptive analysis to analyse the level of application of Malay traditional architecture elements in different categories and analysis. The research identifies that majority of contemporary building design use Malay traditional architecture elements improperly according to the philosophy of Malay traditional culture. The application of Malay traditional architecture character tends to show regional identity in the building design compared to respond ecological considerations. This study also identifies the different result between government buildings and private buildings in the application of Malay traditional architecture elements. The findings indicate the inconsistency of government policy enforcement in building permission to preserve the identity of Malay culture for the improvement of quality of life in Pekanbaru.
\end{abstract}

Keywords: Malay traditional architecture elements, regional identity, sustainable city

\section{Introduction}

Pekanbaru is the capital of Riau province in Sumatra Island with Malay cultural roots as a tradition that has been embedded in everyday life. One of the Riau Province's visions is to become a center of Malay culture in Southeast Asia in 2020. To realize this vision, Pekanbaru City has a role as main indicator in measuring and assessing how the Malay culture in the region can be references about the development of Malay culture in the Southeast Asia region. Architecture is a part of the built environment that is physically able to describe the characteristics and identity of the region. The policy of Pekanbaru City Government which requires the application of Malay architectural character in every design of buildings in urban areas is one effort in maintaining the identity of the region as the land of Malay culture. 
In its development, application of Malay architectural elements in contemporary buildings in Pekanbaru city has shifted from indigenous cultural values. Applications Malay architectural elements is represented in accordance with an understanding of each architect without an understanding the value of philosophical traditions and values of Malay architecture itself. The scopes of this study are focused in; the first is the application rate of Malay traditional architecture elements in the design of contemporary buildings in the city of Pekanbaru. Secondly, the application of Malay traditional architecture elements is assessed based on the values of the philosophy in the tradition of Malay culture, and the third is the evaluation of the Malay traditional architecture elements that has been applied to response the climatic condition. The purpose of this study is to obtain a comprehensive picture of application of Malay traditional architecture elements in the design of contemporary buildings in the city of Pekanbaru. The results of this study may be a reference in evaluating the application of Malay architecture principles in the face of Pekanbaru city to maintain the originality cultural values and improve quality of life of urban communities.

\section{Materials and Method}

\subsection{Literature Review}

In order to achieve sustainable architecture, cultural and ecological contexts should be considered in a complementary relationship (Gülmez, 2007). Cultural context implies a sound respect to the traditional knowledge of place, technology and local materials. Ecological context implies the recycling of energy, either by the use of passive energy or renewable energy. It also requires harmony with local economies and data supporting biological diversity.

Lewis Mumford in The Culture of Cities (1938) reveals that the city is a point where there is maximum concentration of power and culture of a community (Wheeler, 2004). The implication is, the city can be an indicator to measure the strength and existence of the culture of a region. Along with the various challenges and problems of environmental degradation, the issue is how the potential of local wisdom in each area can be explored to improve the quality of urban life while retaining the cultural identity of the region. But the impact of globalization has been damaging and threatening the existence of values of local wisdom, while it is an entity that will determine the dignity of man in his community (Geertz, 1992).

In a cultural context, sustainable architecture reflects the respect to the values and cultural traditions in the application of contemporary architecture as the identity of the city and region. From the aspects of ecology, sustainable architecture can be a solution to the environmental conditions through the adoption and adaptation of local wisdom of vernacular architecture. Local wisdom handed down by the vernacular architecture is the essence of the values of sustainability which can be seen from the character of building. It can overcome environmental problems and reflect the values of high culture at the same time. According to James Ackerman in his article "The History of Design and The Design of History", in creating an experience of a site, the performance of buildings and urban design must be able to create linkages between the social aspects with ecological considerations (Heath, 2009). 


\subsubsection{Malay Traditional Architecture}

Malay house created nearly perfect solution to control of climate, multifunctional use of space, flexibility in design and sophisticated prefabricated system which can extend with the growing needs of family (Yuan, 1987). It is also identifying through riches cultural building components and decorative elements which have meanings that make uniqueness which could be the strongest features. This house, mostly spread in central Sumatera and Malaysian Peninsular, is not just a living house. It is a part origin of people spirit in community and conception of human soul (Waterson, 2009).

It designed with deep understanding and respect to nature. It built closed to sea shore or river side in hinterland area which usually as compound formation that sprawl to each other. Early Malay traditional houses can be described as raised on timber stilts and made of materials which were easily available from the tropical forests such as timber, bamboo, rattan, tree roots and leaves. Usually the houses have pitched roofs, verandahs or porches in front, high ceilings and lots of big openings for ventilation purposes. Although these characteristics are particularly common in all Malay houses throughout the Sumatera and Peninsular Malaysia, their shapes and sizes differ from state to state.

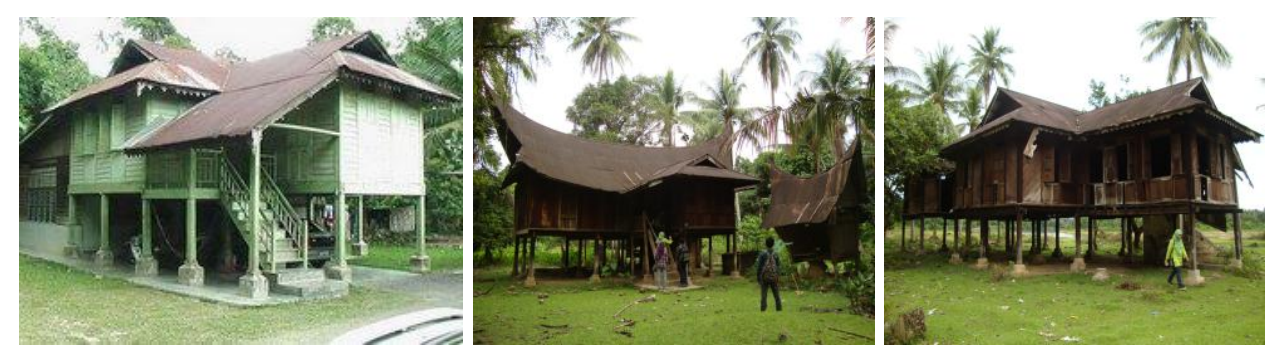

Figure 1. Malay Traditional Houses in Riau

The area where Malay traditional architecture is built is situated in the central part of the Southeast Asia. The region is sunny, hot and humid all year round with temperatures range from $25 \mathrm{C}$ to $34 \mathrm{C}$. It has an annual rainfall from $80 "$ to $100 "$. Due to heavy monsoon rains, the roofs of the Malay traditional houses are very steep. In some places, flooding occurs after heavy rain falls. To solve this problem, some houses have used timber stilts to elevate the building above the ground level. The warm climate also effects the style of the Malay vernacular architecture. For ventilation purposes, many buildings have large openings on the sides and grilles are provided at high level in gable ends. Houses raised on stilts are provided with better natural ventilation.

\subsubsection{Traditional Architecture as a Tool for Sustainable Built Environment}

One important source of energy consumption is definitely the built environment, and architecture is one of the most questioned disciplines that might provide a vast contribution to this struggle of the world. 'Sustainability' as a well known concept is yet an undeniable component of any built environment. Climate and environmental conditions are highly important parameters in a building design. Buildings are designed to achieve or to create a suitable atmosphere for human comfort. Comfort may be defined as the sensation of the complete physical and mental well being of a person within a built Environment. 
Traditional builders used limited resources to achieve maximum comfort and climate was the major determinant in traditional building techniques.

Vernacular Architecture comprises the dwellings and other buildings of the people related to their environmental contexts and available resources, they are customarily owner or community built, utilizing traditional technologies All forms of Vernacular Architecture are built to meet specific needs, accommodating the values, economies and ways of living of the cultures that produce them (Oliver,1997). It must be recognized that many vernacular technologies, resources or forms are suitable and sustainable, although it should not be ignored that some of them are currently no longer properly functioning because of changed cultural and ecological situations. Traditionally builders used knowledge passed from generation to generation to ensure that their buildings could modify the impact of a hostile outdoor environment. Vernacular resources, technologies and forms are generally seen to be well adapted to local climate conditions and are often considered an appropriate base for environmental design (Sundarraja, 2009).

Untutored builders of the vernacular had an admirable talent for suiting buildings to their environment. An extensive knowledge of the climate and ability to modify their buildings meant various ventilation techniques for cooling and reducing solar gains were incorporated into building designs. These principles can be explained through the characteristics of Malay traditional architecture, especially in the design of traditional houses. An elongated floor plan and minimum internal partitions created an easy passage for cross ventilation by reducing friction and fig. 2 indicates how this technique was repeated beneath the house by raising it on stilts. Not only did this help to catch winds of a higher velocity, by shading the ground the air underneath was cooled and drawn up through the floorboards. A high ceiling, typical in tropical vernacular, shows an understanding of the stack effect. Hot air rises with buoyancy and is infiltrated out via ventilation roof joints or in the instance of the Malay funnels shaped roof (bumbung panjang) via grills at each gable end. Solar gains were reduced in the Malay home by large roof overhang.

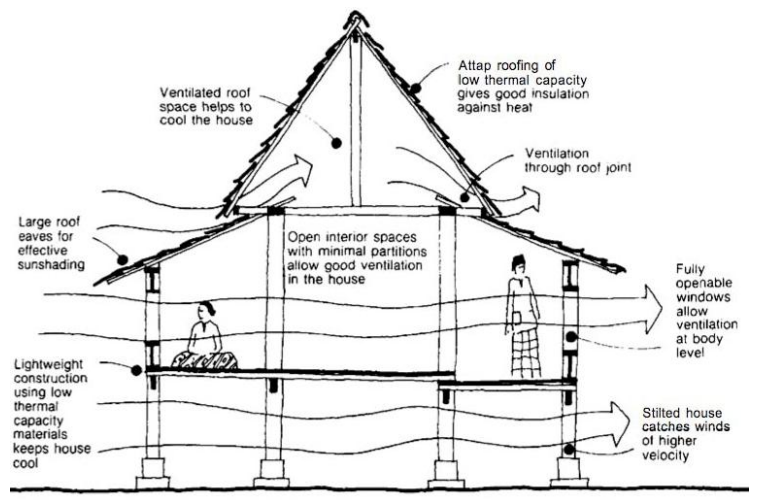

Figure 2. Characteristics of Malay Traditional Houses to Response Local Climate (Source: Yuan, 2011)

\subsection{Methodology}

The study was based on the existing conditions of the city that has a tendency to lose the identity of the region as a result of the intervention a number of contemporary buildings that are not apply Malay architectural elements appropriately. The method used 
in this research is descriptive quantitative method that describes the use of Malay architectural elements in the buildings in the city of Pekanbaru and the type of Malay architectural elements used. Samples of this study are the buildings located along Sudirman Street as main road to connect Sultan Syarif Kasim II airport with Pekanbaru city center. The data was analyzed based on the descriptive analysis about the application rate of Malay architectural elements and types of Malay architectural elements that are used. The evaluation further includes a comparison between government-owned buildings and privately owned buildings or BUMN, and studies regarding the selection of Malay architectural elements that are used by function as an identity, or ecological functions.

\section{Results and Discussions}

The findings of this study identify two variables in achieving sustainable city regarding application of Malay architectural elements in built environment of the city. The variables are based on the application of Malay architectural elements as the preservation of culture values and as a response of ecological condition.

\subsection{Application of Malay Architectural Elements as Regional Identity}

Vellinga (2005) in his article entitled "Anthropology and the Challenges of Sustainable Architecture" focuses on understanding of how the building is connected with the process of social identification. The principles of sustainable architecture must consider the sustainability aspect of cultural values and traditions in the design of buildings in urban areas. Pekanbaru city as the capital of Riau Province which has a vision to be a center of Malay culture in Southeast Asia in 2020 needs to be assessed on the application level of Malay architectural elements in the built environment of the city. From the data obtained, it is known that only $31 \%$ of the buildings along the path of General Sudirman apply Malay traditional architecture elements in their design (Fig.3). The applications of Malay architectural elements are divided into three main elements which are roof design, the "selembayung" and ornament or Malay traditional carving

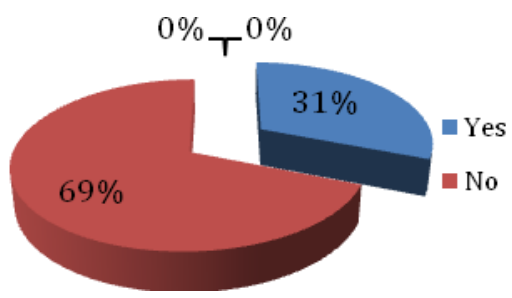

Figure 3. Application Level of Malay Architecture Elements (Author, 2012) 

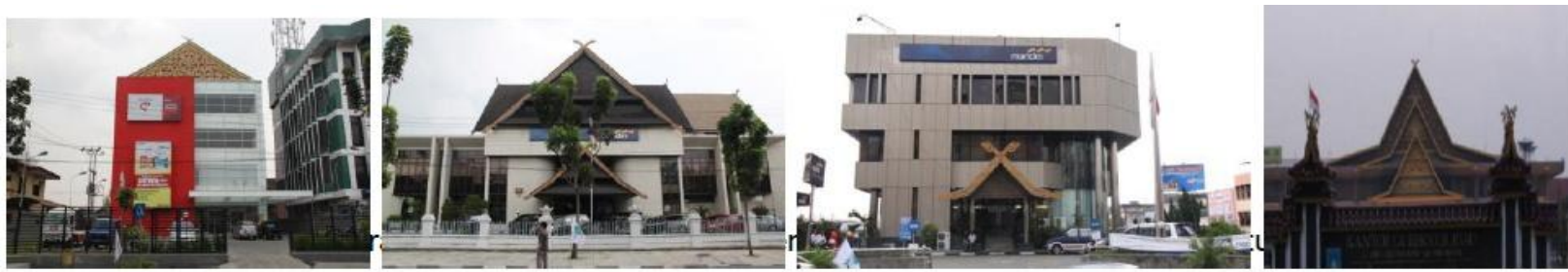

Figure 4. Performance of Buildings with Application of Malay Architecture Elements (Author, 2012)

Based on the function of the building, this study identified that the buildings which apply Malay architectural elements consistently are owned by local governments, where $78 \%$ of local government buildings are designed with Malay traditional architecture character. Meanwhile the buildings that do not apply Malay architectural elements in their design are identified as non-government or private owned buildings. Only 25\% private buildings have Malay traditional architecture elements in their design, and shop houses along the road that apply it are not more than 15\% (Fig.5).

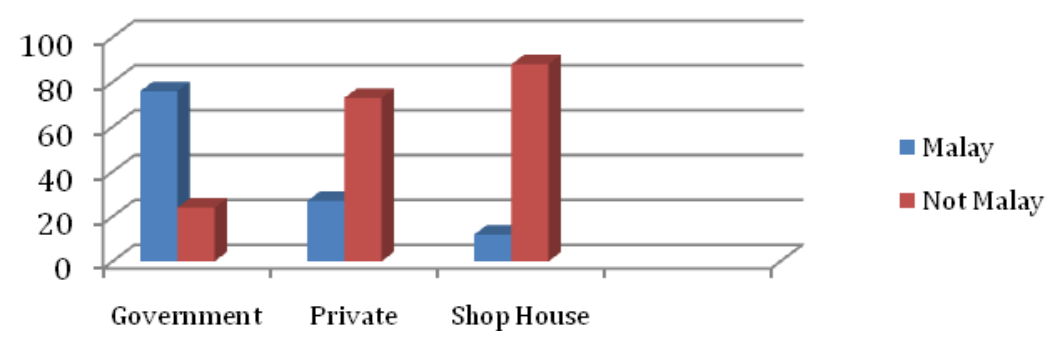

Figure 5. Application Level of Malay Architecture Elements

In the application of Malay traditional architecture elements, the designs used are often incompatible with the philosophy of Malay traditional architecture and its culture. Some buildings especially those owned by local governments, apply Malay architectural elements in accordance with the philosophy. However, for buildings owned by state-owned enterprises and private tend to apply Malay architectural elements as a symbol of Malay character to accommodate the requirement of buildings permission in the city of Pekanbaru. Based on the analysis of building performance regarding application of Malay architecture elements, this study found that application of Malay traditional architecture elements in the buildings are not based on the philosophy of Malay culture values. The contemporary building design tends only to accommodate the requirement given by local authority to apply Malay traditional architecture character in their design. 


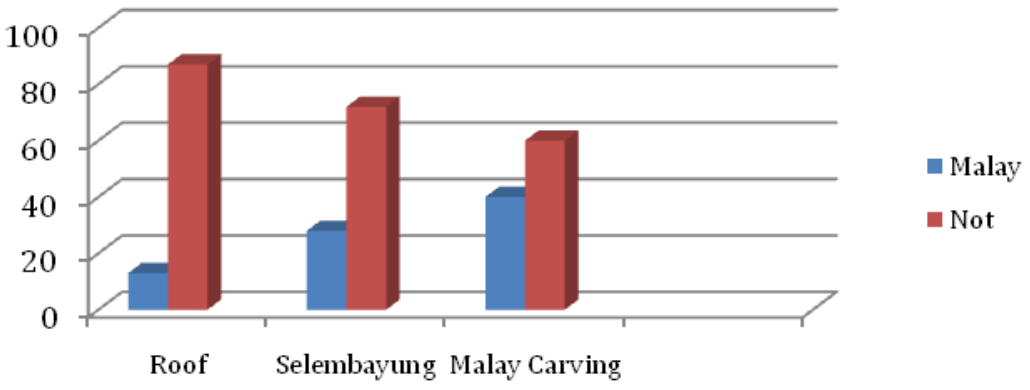

Figure 6. Application Level of Malay Architecture Elements
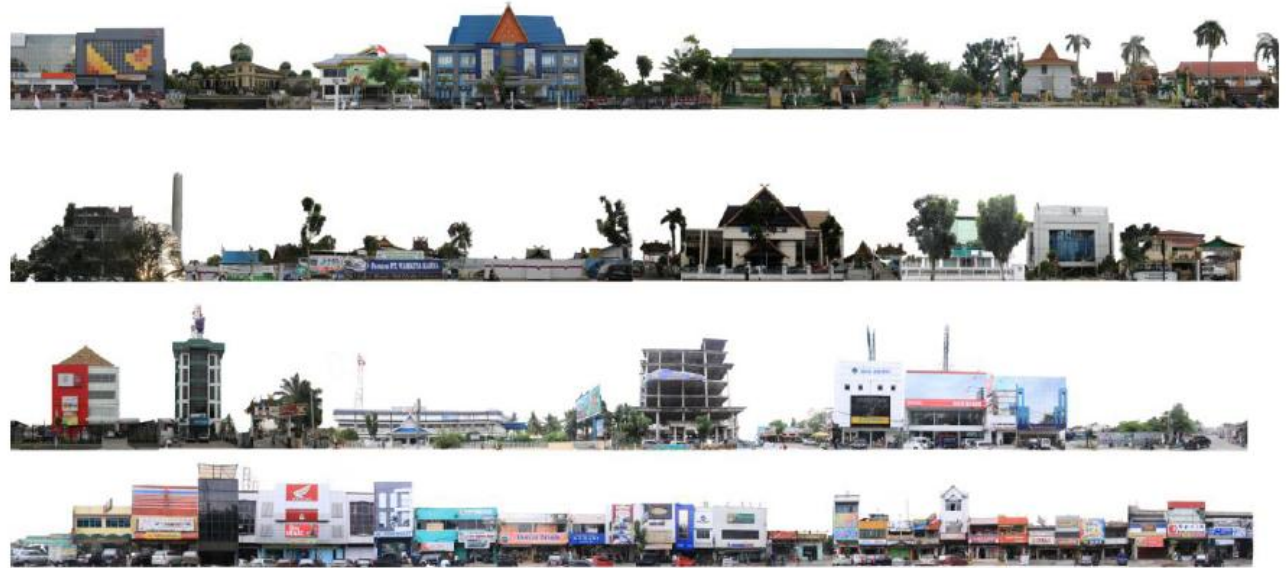

Figure 7. Performance of Buildings with Application of Malay Architecture Elements

\subsection{Application of Malay Architectural Elements as Ecological Response}

According Gülmez (2007), examples of vernacular architecture that was built in several different areas could be a practical solution to the problems of geography and climate, which it must be viewed as sensitivity to the surroundings. From the data obtained the use of Malay architectural element dominated by the use "selembayung" as a symbol of Malay traditional architecture and its culture. It is followed by the use of Malay traditional architectural roof element. While the application of typical Malay carvings and ornaments amounted to $31 \%$.

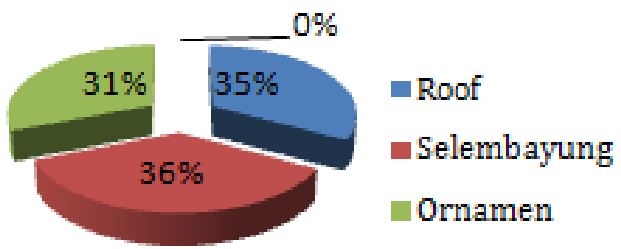

Figure 8. Analysis of Preference of Applied Malay Architecture Elements 


\section{Conclusion}

Results of this study illustrate that the level of application of Malay traditional architecture elements is still low and the majority among the buildings that apply Malay traditional architectural elements does not apply them correctly in accordance with the philosophy of Malay cultural values it self. Analysis of the study based on the application Malay traditional architectural elements in contemporary buildings in the city of Pekanbaru, the majority of them tends to use ornaments or carvings and "selembayung" as identity and aesthetic functions. While a typical roofing application of traditional Malay architecture used by only a third of the total number of buildings along the way Sudirman Street. From the survey results above, it can be concluded that contemporary buildings in the city of Pekanbaru apply Malay architectural elements only as an identity, rather than using the values of local wisdom to solve the issue of climatic and thermal conditions. While among the buildings that make the application of Malay traditional architectural elements as regional identity, majority of them does not understand the values and traditions of philosophical background to a Malay architectural elements are used. In addition there are significant differences between the government-owned buildings with privately owned buildings in the use of Malay traditional architectural elements.

According to Oliver (2006), a tradition is not enough to sustain a culture, because in today's modern world, cultural values must be transformed into something that suits your needs and be a practical solution in the community. The results could be used as an evaluation for the City of Pekanbaru and Riau Province in creating the face of the city that really has a strong identity as a Malay cultural region. Also in the context of sustainable city, Malay traditional architectural elements applications should support the vision of Riau province on one side, and the other side it can be a solution for improving the quality of urban living through the designs of buildings that are responsive to environmental conditions.

\section{Acknowledgement}

The author would like to express gratitude towards the colleagues in the Department of Architecture in the University of Riau. I would like to thank the students who have finished the field survey in completing this study and to government officials in Pekanbaru who have assisted the author to finish this work.

\section{References}

Heath, Kingston WM. 2009. Vernacular Architecture and Regional Design: Cultural Process and Environmental Response. Oxford: Architectural Press.

Gülmez, Nilay Ü., and Uraz, Türkan U. 2007. Vernacular Urban Fabric as a Source of Inspiration for Contemporary Sustainable Urban Environments : Mardin and the case

of "Mungan House". Rotterdam: International Conference on Sustainable Urban Areas.

Oliver, Paul. 1997. Encyclopedia of Architecture. Cambridge: Cambridge University Press.

Oliver, Paul. 2006. Built to Meet Needs: Cultural Issues in Vernacular Architecture. Oxford: Architectural Press. 
Sundarraja, M.C., Radhakrishnan, S. 2009. Understanding Vernacular Architecture as a Tool for Sustainable Built Environment. India: 10th National Conference on Technological Trends (NCTT09).

Vellinga, M. 2005. Anthropology and the Challenges of Sustainable Architecture. Anthropology Today, Vol 21 No3, pp. 3-7.

Waterson, Roxana. 2009. The Living House, An Anthropogy Of Architecture in South-East Asia. Singapore: Tuttle Publishing,.

Yuan, Lim Jee. 1987. The Malay House, Rediscovery Malaysia's Indegenous Shelter System. Malaysia: The Phonix Press. 